\title{
Effect of formic acid and benzoic acid esters on grass preservation
}

\author{
A Rauramaa 1, A Tommila 1, J Nousiainen ' \\ IValio Ltd, Farm Services, PO Box 390, 00101 Helsinki ; 2 Kemira Agro Ltd, \\ Espoo Reseach Centre, PO Box 44, 02271 Espoo, Finland
}

Formic acid is known to improve silage hygienic quality. Formic acid based additive containing propionic and benzoic acids inhibits more effectively growth of undesired microbes according to Mannerkorpi and Rauramaa (1993, The 10th International Conference on Silage Research: Dublin City Univercity, 188189) and Rauramaa et al (1993, 6 Mezinarodni symposium Konzervac objemnych krimv: Pohorelice, 223-224). However benzoic acid will crystallize very easily during storage, if temperature of additive is near $0^{\circ} \mathrm{C}$. The other reason for searching further alternatives for benzoic acid and propionic acid was the high prices of these components. The esters of benzoic acid are solutions and they are known in preservation (1983, Patent $\mathrm{Fl}$ 63328). The purpose of this work was to study the effect of formic acid based additive, containing benzoic acid ester and/or propyl formate, on silage quality.

The experiment was carried out in laboratory scale using precision chopped timothymeadow-fescue grass from the third sward of the summer 1994. Chopped grass $(1 \mathrm{~kg})$ was treated and placed into airtight plastic bags, which were closed by heat sealing and stored at $18^{\circ} \mathrm{C}$ for 48 days. Then plastic silos were opened, sampled and the rest of silages was stored for 10 days at $18^{\circ} \mathrm{C}$ in styrox boxes. Aerobic deterioration of silages were followed by measuring temperature. The grass treatments were : no additive (NO), $80 \%$ formic acid and $2 \%$ o-phosphoric acid (AIV 2), $2 \%$ o-phosphoric and 78,76 or $74 \%$ formic acid plus correspondingly 2, 4 or $6 \%$ ethyl benzoate (EB2, EB4, EB6), propyl formate (PF2, PF4, PF6) or ethyl benzoate and propyl formate (1:1) $(E B+P F 2, E B+P F 4, E B+$ $P F 6)$. Each treatment was replicated five times. The silages were analyzed by titration method (1989, Moisio and Heikonen, Anim Feed Sci technol, 22, 341-353).

The results of chemical analyses are shown in table. According to temperature measurements aerobic deterioration was highest in silage made with no additive. The increase of temperature was significantly lower in all test silages compared to AIV 2 and NO silages.

The results suggest that in making silage of low dry matter grass the use of ethyl benzoate and/or propyl formate with formic acid improves silage quality and inhibits aerobic deterioration.

\begin{tabular}{lcccccc} 
Silage & $\mathrm{pH}$ & $\begin{array}{c}\text { Lactic } \\
\text { acid }\end{array}$ & $\begin{array}{c}\text { Acetic } \\
\text { acid }\end{array}$ & $\begin{array}{c}\text { Reducing } \\
\text { sugars }\end{array}$ & $\begin{array}{c}\mathrm{NH}_{3}+\text { amines } \\
\mathrm{N} \% \text { of total } \mathrm{N}\end{array}$ & $\begin{array}{c}\text { Sum of temperature } \\
\text { Increases in 10 days }\end{array}$ \\
\cline { 3 - 6 } NO & 3.79 & 110.8 & 17.2 & 29.4 & 26.36 & ${ }^{\circ} \mathrm{C}$ \\
AIV 2 & 3.76 & 65.4 & 8.8 & 40.4 & 8.07 & 44.3 \\
EB2 & 3.86 & 55.6 & 7.0 & 57.8 & 4.84 & 20.6 \\
EB4 & 3.84 & 62.8 & 7.4 & 52.2 & 5.41 & 18.1 \\
EB6 & 3.80 & 64.2 & 10.0 & 29.8 & 4.94 & 16.4 \\
PF2 & 3.75 & 71.8 & 11.2 & 17.4 & 6.28 & 12.0 \\
PF4 & 3.69 & 72.4 & 7.2 & 32.6 & 5.40 & 12.8 \\
PF6 & 3.71 & 81.2 & 12.2 & 11.0 & 8.35 & 12.5 \\
EB+PF2 & 3.64 & 81.4 & 5.0 & 38.0 & 4.83 & 16.2 \\
EB+PF4 & 3.67 & 73.8 & 5.0 & 33.6 & 7.41 & 10.2 \\
EB+PF6 & 3.88 & 56.0 & 5.6 & 95.8 & 4.05 & 11.9 \\
\hline
\end{tabular}

Mean dry matter content of silages were $164 \mathrm{~g} / \mathrm{kg}$. 